NBER WORKING PAPER SERIES

\title{
RECRUITING INTENSITY DURING AND AFTER THE GREAT RECESSION: NATIONAL AND INDUSTRY EVIDENCE
}

\author{
Steven J. Davis \\ R. Jason Faberman \\ John C. Haltiwanger \\ Working Paper 17782 \\ http://www.nber.org/papers/w17782
NATIONAL BUREAU OF ECONOMIC RESEARCH
1050 Massachusetts Avenue
Cambridge, MA 02138
January 2012

We thank Mike Elsby for comments and Taft Foster for excellent research assistance. The views expressed here are those of the authors and do not reflect those of the Federal Reserve Bank of Chicago, the Federal Reserve System, or the National Bureau of Economic Research.

NBER working papers are circulated for discussion and comment purposes. They have not been peerreviewed or been subject to the review by the NBER Board of Directors that accompanies official NBER publications.

(C) 2012 by Steven J. Davis, R. Jason Faberman, and John C. Haltiwanger. All rights reserved. Short sections of text, not to exceed two paragraphs, may be quoted without explicit permission provided that full credit, including $(\mathcal{C}$ notice, is given to the source. 
Recruiting Intensity during and after the Great Recession: National and Industry Evidence Steven J. Davis, R. Jason Faberman, and John C. Haltiwanger

NBER Working Paper No. 17782

January 2012

JEL No. E24,J63

\begin{abstract}
$\underline{\text { ABSTRACT }}$
We measure job-filling rates and recruiting intensity per vacancy at the national and industry levels from January 2001 to September 2011 using data from the Job Openings and Labor Turnover Survey. Construction makes up less than 5 percent of employment but accounts for more than 40 percent of the large swings in the job-filling rate during and after the Great Recession. Leisure \& Hospitality accounts for nearly a quarter of the large drop in recruiting intensity during the Great Recession. We show that industry-level movements in job-filling rates and recruiting intensity are at odds with the implications of the standard matching function in labor search theory but consistent with a generalized function that incorporates an important role for recruiting intensity per vacancy.
\end{abstract}

Steven J. Davis

Booth School of Business

The University of Chicago

5807 South Woodlawn Avenue

Chicago, IL 60637

and NBER

Steven.Davis@ChicagoBooth.edu

R. Jason Faberman

Economic Research Department

Federal Reserve Bank of Chicago

230 S. LaSalle St.

Chicago, IL 60604

jfaberman@frbchi.org
John C. Haltiwanger

Department of Economics

University of Maryland

College Park, MD 20742

and NBER

haltiwan@econ.umd.edu 
The number of unemployed persons per vacancy more than tripled during the 2008-09 recession. The ratio fell after July 2009 but remains more than double its pre-recession level as of September 2011. According to the standard matching function in labor search theory, this path for the ratio of unemployment to vacancies implies a similar path for the fill rate of vacant job positions. The actual job-filling rate, however, does not conform to the path implied by standard theory. In Davis, Faberman and Haltiwanger (2010, DFH hereafter), we account for part of the gap between actual and implied fill-rate movements using a generalized matching function that incorporates a role for recruiting intensity per vacancy. "Recruiting intensity" is shorthand for the other instruments employers use to influence the pace of new hires - e.g., advertising expenditures, screening methods, hiring standards, and the attractiveness of compensation packages. These instruments affect the number and quality of applicants per vacancy, the speed of applicant processing, and the acceptance rate of job offers. Conditional on the vacancy-to-unemployment ratio, a higher recruiting intensity per vacancy raises the fill rate.

In our earlier work, we measure the U.S. job-filling rate and construct a national index for recruiting intensity per vacancy. In this paper, we construct national and industry measures of the fill rate and recruiting intensity. We find that Construction and a few other industries play disproportionately large roles in the national movements of these two series. In other words, industries differ greatly in the cyclical behavior of job-filling rates and recruiting intensity. We show that industry-level movements in these variables during and after the Great Recession are inconsistent with the standard matching function but consistent with our generalized function.

\footnotetext{
${ }^{1}$ Davis (2011) accounts for an additional part of the gap by further generalizing the matching function to capture a role for search intensity per unemployed person. Other researchers explore the role of mismatch in the breakdown of the standard matching function and recent instability in the Beveridge curve. See, for example, Michael Elsby, Bart Hobijn, and Ayşegül Şahin (2010), Regis Barnichon and Andrew Figura (2011), Şahin, Jae Song, Giorgio Topa, and Gianluca Violante (2011), and Benedikt Herz and Thijs van Rens (2011).
} 


\section{Data and Measurement}

The Job Openings and Labor Turnover Survey (JOLTS) samples about 16,000 establishments per month and yields data on employment, the number of hires and separations during the month, and the number of vacancies on the last business day of the month. We use JOLTS micro data from December 2000 to June 2011 and published JOLTS statistics through September 2011. DFH develop a method to estimate the daily job-filling rate using JOLTS data. Here, we apply the DFH method to estimate national, industry and regional job-filling rates.

DFH also show that the log of the job-filling rate rises strongly with the log of the gross hires rate in the cross section of establishments. As DFH discuss, there are two ways to reconcile this empirical relationship with standard search theory. One is to posit increasing returns to scale in the employer-level hiring technology, so that it becomes easier for an employer to fill any given vacancy the higher its vacancy rate. A second way is for recruiting intensity per vacancy to covary positively with the vacancy rate in the cross section. DFH develop evidence of constant returns in the employer-level hiring technology and specify the generalized matching function accordingly.

The resulting generalized matching function yields an aggregate job-filling rate

$$
f_{t}=\mu(v / u)_{t}^{-\alpha} q_{t}^{1-\alpha}
$$

where $\mu$ is a matching efficiency parameter, $-\alpha$ is the elasticity of the fill rate with respect to the vacancy-unemployment, or $v-u$, ratio, and $q_{t}$ is the vacancy-weighted mean of the employerlevel recruiting intensity per vacancy in month $t$. As DFH discuss, cross-sectional evidence supports a recruiting intensity specification given by $\ln q_{t}=\varepsilon \ln H_{t}$, where $\varepsilon$ is the empirical elasticity of the fill rate with respect to the gross hires rate. DFH construct a national recruiting 
intensity index using data on the aggregate gross hires rate and an empirical elasticity $\varepsilon=0.82$. They show that the resulting fill rate given by (1) more closely tracks the observed national fill rate than the one implied by the standard matching function with no role for $q_{t}$. Incorporating a role for the recruiting intensity index also improves the stability of the Beveridge Curve and yields a better fit to data on the job-finding rate for unemployed workers.

Motivated by the greater success of the generalized matching function in accounting for the cross-sectional and time-series evidence, we construct an index of recruiting intensity per vacancy for each industry, letting the elasticity $\varepsilon$ vary by industry. We use the experienced unemployed from the Current Population Survey (CPS) along with JOLTS vacancy data to compute the industry $v-u$ ratios by month. An unpublished appendix presents regional time series for recruiting intensity and the job-filling rate and other results.

\section{Recruiting Intensity and Job Filling since the Great Recession}

Figure 1 plots national time series for the job-filling rate and recruiting intensity per vacancy. The job-filling rate rose sharply, from 4.4 percent per day in December 2007 to a peak of 6.6 percent per day in August of 2009. It fell steadily thereafter, though it remains above prerecession levels at 4.8 percent per day as of September 2011. Recruiting intensity per vacancy fell sharply during the Great Recession, declining by over 21 percent between December 2007 and its trough. It remains 11 percent below its pre-recession level as of September 2011. 
Figure 1. Job-Filling Rate and Recruiting Intensity per Vacancy, January 2001 to September 2011

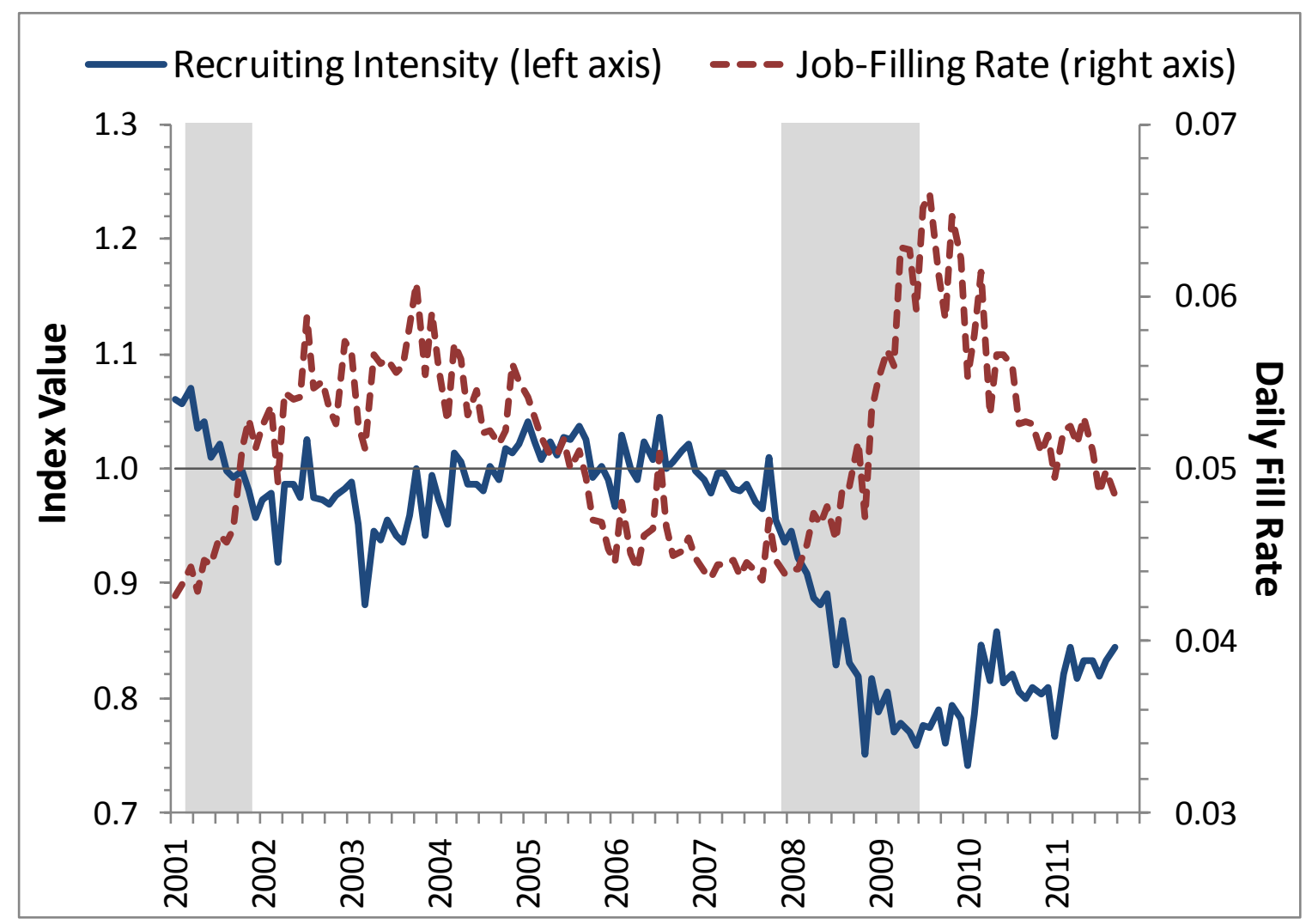

Source: Authors' calculations using JOLTS micro data. See text and DFH for descriptions of how to calculate the job-filling rate and recruiting intensity per vacancy. Recruiting intensity is scaled so that its 2004-07 average equals one. Shaded areas show NBER recessions.

Table 1 reports the contribution of selected industries to changes in the national jobfilling rate and recruiting intensity index during the recession and recovery periods. Relative to 2007Q4, the job-filling rate rose 39 percent during the recession and fell 21 percent from 2009Q2 to 2011Q2. ${ }^{2}$ Remarkably, Construction accounts for more than 40 percent of the swings in the national job-filling rate during and after the recession, despite making up less than 5 percent of employment. Relative to $2007 \mathrm{Q} 4$, recruiting intensity per vacancy fell by 22 percent

\footnotetext{
${ }^{2}$ We report results for quarterly averages in Table 1 , because the monthly industry-level data are noisy.
} 
during the recession but rose only 6 percent from 2009Q2 to 2011Q2. Construction plays almost no role in the national drop in recruiting intensity, while the Leisure \& Hospitality sector plays a major role. Professional \& Business Services, Manufacturing and Construction largely account for the small post-recession recovery in recruiting intensity. Despite making up nearly 15 percent of employment and expanding throughout the recession, Health and Education account for very modest shares of movements in the fill rate and recruiting intensity index. Government also plays a disproportionately small role; in fact, recruiting intensity per vacancy in Government fell during the recovery even as national recruiting intensity rose.

Table 1. Contributions to Changes in the Job-Filling Rates and Recruiting Intensity per Vacancy

\begin{tabular}{|lccccc|}
\hline & & \multicolumn{2}{c}{ Job-Filling Rate } & \multicolumn{2}{c|}{ Recruiting Intensity } \\
& Employment & $\mathbf{2 0 0 7 : 4 -}$ & $\mathbf{2 0 0 9 : 2 -}$ & $\mathbf{2 0 0 7 : 4 -}$ & $\mathbf{2 0 0 9 : 2}-$ \\
& Share, 2007:4 & $\mathbf{2 0 0 9 : 2}$ & $\mathbf{2 0 1 1 : 2}$ & $\mathbf{2 0 0 9 : 2}$ & $\mathbf{2 0 1 1 : 2}$ \\
\hline Percent Change, & & 39.0 & -22.0 & -21.8 & 5.9 \\
Relative to 2007Q4 & & \multicolumn{3}{c}{ Contribution to National Change, Percent } \\
\hline Selected Industry & & 43.0 & 41.9 & 2.4 & 27.6 \\
Construction & 4.7 & 12.5 & 16.2 & 11.6 & 22.3 \\
Manufacturing & 9.0 & 8.9 & 5.0 & 14.2 & 44.2 \\
Professional \& & 12.6 & 9.4 & 4.6 & 24.1 & 8.9 \\
Business Services & 10.1 & 4.6 & 3.6 & 7.2 & -0.6 \\
Leisure \& Hospitality & 14.6 & 1.6 & 4.3 & 6.2 & -15.6 \\
Health and Education & 17.4 & & &
\end{tabular}

Source: Authors' calculations using JOLTS micro data.

Figure 2 plots three-month moving averages of the cross-industry variance in the logs of the job-filling rate, recruiting intensity per vacancy, and $v-u$ ratio. We weight industries in proportion to employment in computing these variance measures. The industry dispersion of job-filling rates rose from 8 to $16 \log$ points during the Great Recession, then fell in a rather erratic manner during the recovery to stand at $10 \log$ points in September 2011. The dispersion in the $v-u$ ratio behaves similarly in the recession but declines rapidly in the recovery and returns to 
its pre-recession level by July 2011. These two industry dispersion measures behave similarly to closely related measures of "mismatch" in the labor market developed by Şahin et al. (2011). By way of comparison, movements over time in the industry dispersion of recruiting intensity per vacancy are modest. The industry dispersion in recruiting intensity actually rose in 2010 and 2011, even as dispersion in job filling and the $v-u$ ratio fell.

Figure 2. Cross-Industry Dispersion Measures, January 2001 to September 2011

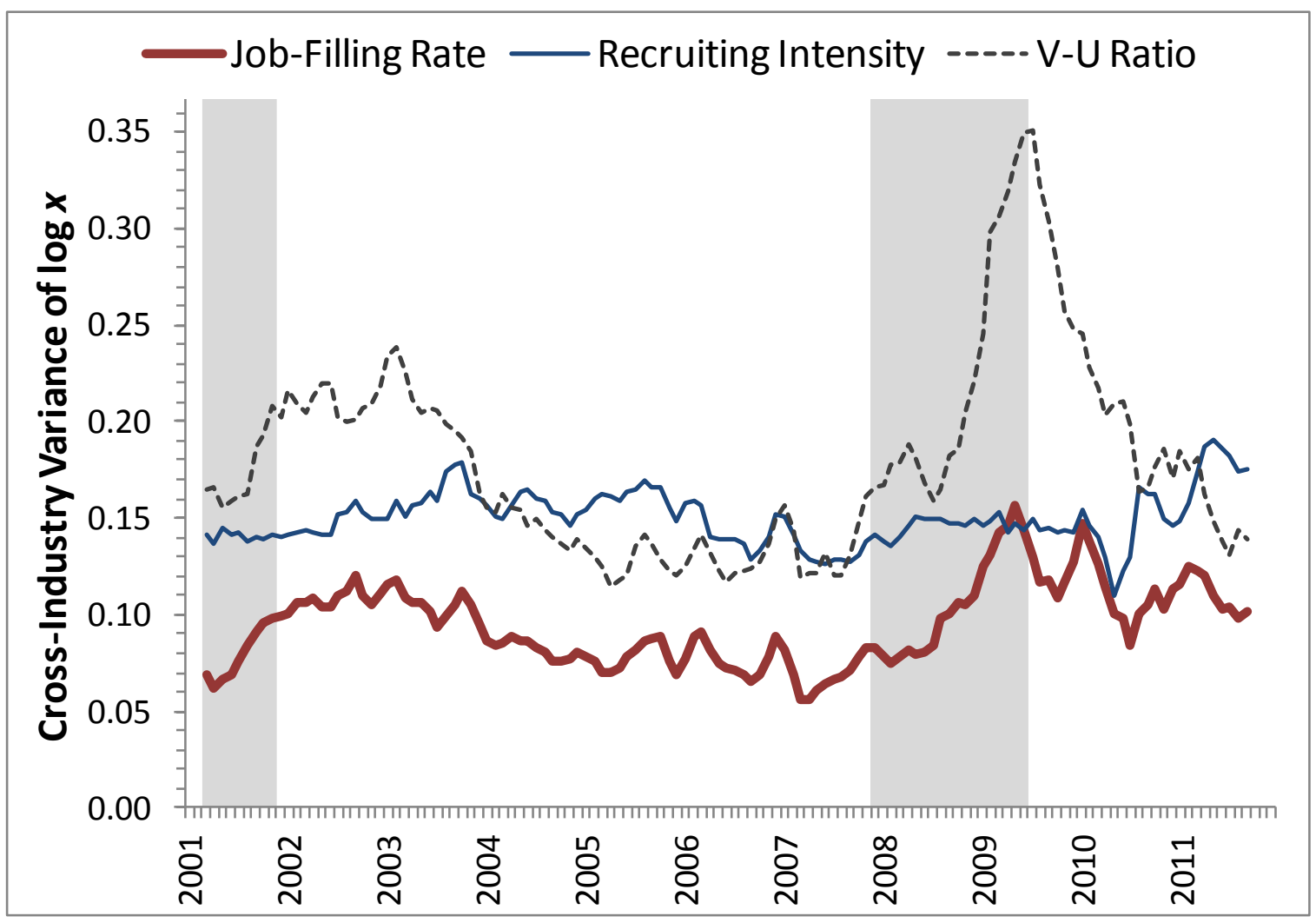

Source: Authors' calculations using JOLTS micro data. Figure depicts the employment-weighted variances of the log of each variable across 12 NAICS industries.

Figure 3 plots industry changes in the log job-filling rate and log recruiting intensity per vacancy against changes in the $\log v-u$ ratio in the recession and recovery periods. The left panel shows that both periods exhibit a strong negative relationship between industry changes in the fill rate and $v-u$ ratio. The slope of the relationship is -0.49 during the recession and -0.28 
afterward. Each slope is statistically significant at the 5 percent level, but the difference between them is not. The right panel shows that changes in recruiting intensity are essentially unrelated to changes in the vacancy-unemployment ratio during the recession. After the recession, however, a tight positive relationship holds between the two. The increase in the slope is large (from 0.04 to 0.31 ) and, despite the small sample, statistically significant at the $5 \%$ level.

\section{Figure 3: The Relation between Industry Changes in the Job Filling Rate, Recruiting Intensity Per Vacancy, and the Vacancy-Unemployment Ratio}
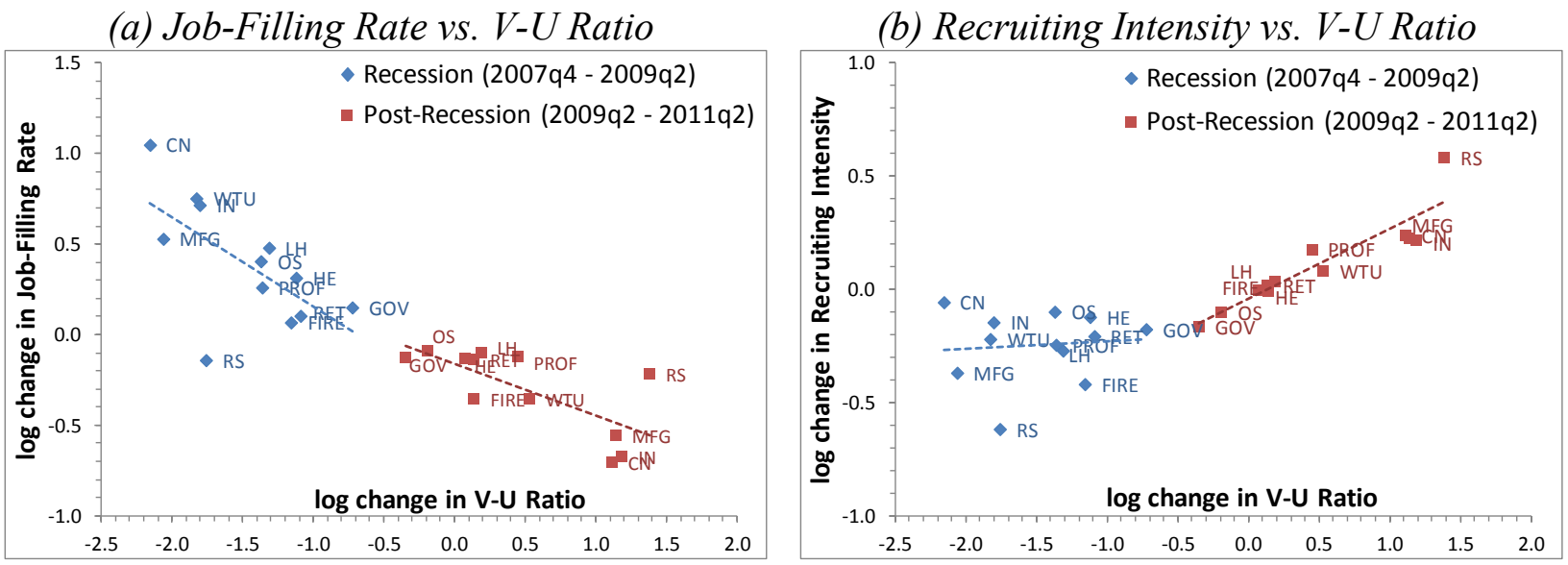

Source: Authors' calculations using JOLTS micro data. Industry abbreviations: RS (Resources), CN (Construction), MFG (Manufacturing), WTU (Wholesale, Transport \& Utilities), RET (Retail), IN (Information), FIRE (Finance, Insurance \& Real Estate), PROF (Professional \& Business Services), HE (Health \& Education), LH (Leisure \& Hospitality), OS (Other Services), GOV (Government).

The patterns in Figure 3 are broadly consistent with the generalized matching function that underlies (1) but inconsistent with the standard matching function. To see these points, consider the case with a uniform matching function elasticity across industries. Take natural logs and time differences in the industry-level counterparts to (1) to obtain

$$
\frac{\Delta \ln f_{i t}}{\Delta \ln (v / u)_{i t}}=(1-\alpha) \frac{\Delta \ln q_{i t}}{\Delta \ln (v / u)_{i t}}-\alpha .
$$


There is no role for recruiting intensity per vacancy in the standard matching function, so the first term on the right side of (2) vanishes. This feature of the standard matching function is at odds with the strong positive slope in Figure 3(b) for the post-recession period. Moreover, the standard matching function implies a time-invariant negative relationship between the numerator and denominator on the left side of (2). Despite the small number of data points, our sample produces mild evidence against this implication as well.

The generalized matching function implies a more subtle restriction on the empirical relations in Figure 3, as encapsulated by (2). For the recession period, Figure 3 gives estimates $\Delta \ln f / \Delta \ln (v / u)=-0.49$ and $\Delta \ln q / \Delta \ln (v / u)=0.04$. Plugging these values into (2) and solving yields $\alpha=0.51$. For the post-recession period, we have $\Delta \ln q / \Delta \ln (v / u)=0.31$ from Figure 3(b). Plugging into (2) and evaluating at $\alpha=0.51$ implies a value of -0.35 for $\Delta \ln f / \Delta \ln (v / u)$, close to the actual post-recession value of -0.28 . Thus, the evidence in Figure 3 is consistent with restriction (2) and the underlying generalized matching function.

In summary, Table 1 and Figures 2 and 3 highlight large differences across industries in the cyclical behavior of job-filling rates and recruiting intensity per vacancy. The evidence in Figure 3 is at odds with the standard matching function but consistent with a generalized matching function that includes an important role for fluctuations in recruiting intensity per vacancy. An open question is what drives the pronounced industry-specific variation in job filling and recruiting intensity. We do not address that question here, but our analysis suggests that it warrants attention in future research. 


\section{Concluding Remarks}

We find large differences across industries in the evolution of job-filling rates and recruiting intensity per vacancy during and after the Great Recession. Construction makes up less than 5 percent of employment but accounts for more than 40 percent of the large swings in the national job-filling rate over the past four years. Leisure \& Hospitality makes up 10 percent of employment but accounts for nearly a quarter of the drop in recruiting intensity during the recession. While Government, Health and Education jointly account for nearly a third of employment, their contribution to national movements in job filling and recruiting intensity is quite modest - less than 5 percent of swings in the job-filling rate, for example.

The outsized role of Construction in the behavior of national job-filling rates raises concerns about theories that abstract from industry differences in matching frictions. In this regard, we note that Construction is highly atypical in terms of its "frictional" characteristics. As reported in the online appendix, the job-filling rate in Construction is more than double that of any other industry. Mean vacancy duration in Construction was 8 days prior to the recession and only 3 days at the trough. In short, a small highly atypical sector accounts for much of the recent movements in the national job-filling rate. Another concern pertains to the nature and role of wage rigidities. As stressed by Robert E. Hall (2005), for example, search frictions create room for wage rigidity on the hiring margin. In turn, wage rigidity on the hiring margin amplifies the response of job creation and unemployment to aggregate shocks. In light of our statistics on jobfilling rates, there appears to be little scope for search-based wage rigidities in the highly cyclical Construction sector. Of course, wage rigidities may arise for reasons unrelated to search frictions. 
Like the earlier work in DFH on which we build, this paper points to an important role for recruiting intensity in the cyclical relationship among hires, vacancies and unemployment. Data limitations, however, require an indirect approach to the measurement of recruiting intensity per vacancy. There is a need to develop data that support more direct measures. A natural approach is to expand existing surveys, such as the JOLTS, to inquire about the instruments and methods that employers use to recruit new hires. A simple suggestion that avoids undue respondent burden is to include a list of recruitment methods on the survey instrument and to ask respondents with vacancies to check off the methods they use - screening of unsolicited applications, word of mouth, referrals from existing employees, help-wanted advertisements in print media, web postings, the use of employment agencies, internships, evaluation of temp workers, and so on. 


\section{References}

Barnichon, Regis and Andrew Figura. 2011. "What Drives Matching Efficiency? A Tale of Decomposition and Dispersion." Federal Reserve Board of Governors Working Paper 2011-10.

Davis, Steven J. 2011. Comment on "Job Search, Emotional Well-Being and Job Finding in a Period of Mass Unemployment." Brookings Papers on Economic Activity, David H. Romer and Justin Wolfers (eds.), Spring: 58-78.

Davis, Steven J., R. Jason Faberman, and John C. Haltiwanger. 2010. "The Establishment-Level Behavior of Vacancies and Hiring." National Bureau of Economic Research Working Paper No. 16265.

Elsby, Michael W. L., Bart Hobijn, and Ayşegül Şahin. 2010. "The Labor Market in the Great Recession." In Brookings Papers on Economic Activity, David H. Romer and Justin Wolfers (eds.), Spring: 1-48.

Hall, Robert E. 2005. "Employment Fluctuations with Equilibrium Wage Stickiness." American Economic Review, 95, no. 1, 50-65.

Şahin, Ayşegül, Jae Song, Giorgio Topa, and Gianluca Violante. 2011. "Measuring Mismatch in the U.S. Labor Market.” Unpublished.

Herz, Benedikt, and Thijs Van Rens. 2011. “Structural Unemployment.” Unpublished. 


\section{Appendix for "Recruiting Intensity during and after the Great Recession: National and Industry Evidence"}

By Steven J. Davis, R. Jason Faberman, and John C. Haltiwanger

\section{Supplemental Results by Industry and Region}

Table A.1. Contributions to Changes in the Job-Filling Rates and Recruiting Intensity Per Vacancy

\begin{tabular}{|c|c|c|c|c|c|c|}
\hline & \multirow[b]{2}{*}{$\begin{array}{l}\text { Fill Rate } \\
\text { Elasticity }\end{array}$} & \multirow[b]{2}{*}{$\begin{array}{c}\text { Employment } \\
\text { Share, } \\
2007: 4\end{array}$} & \multicolumn{2}{|c|}{ Job-Filling Rate } & \multicolumn{2}{|c|}{ Recruiting Intensity } \\
\hline & & & $\begin{array}{l}\text { 2007:4 - } \\
\text { 2009:2 }\end{array}$ & $\begin{array}{c}2009: 2- \\
2011: 2\end{array}$ & $\begin{array}{c}2007: 4- \\
2009: 2\end{array}$ & $\begin{array}{c}\text { 2009:2 - } \\
\text { 2011:2 }\end{array}$ \\
\hline $\begin{array}{l}\text { Percent Change, Relative } \\
\text { to } 2007 \text { Q }\end{array}$ & 0.812 & & 39.0 & -22.0 & -21.8 & 5.9 \\
\hline Industry & & & \multicolumn{4}{|c|}{ Contributions to National Changes } \\
\hline Resources & 0.773 & 0.5 & -0.4 & 0.4 & 1.5 & 4.9 \\
\hline Construction & 0.745 & 4.7 & 43.0 & 41.9 & 2.4 & 27.6 \\
\hline Manufacturing & 0.783 & 9.0 & 12.5 & 16.2 & 11.6 & 22.3 \\
\hline $\begin{array}{l}\text { Wholesale, Transport, } \\
\text { and Utilities }\end{array}$ & 0.789 & 7.9 & 9.7 & 9.2 & 9.7 & 7.5 \\
\hline Retail Trade & 0.782 & 11.0 & 5.3 & 7.6 & 11.7 & 3.2 \\
\hline Information & 0.897 & 2.1 & 2.2 & 2.6 & 2.0 & 3.3 \\
\hline $\begin{array}{l}\text { Finance, Insurance, and } \\
\text { Real Estate }\end{array}$ & 0.864 & 5.9 & 0.2 & 3.4 & 7.5 & -0.2 \\
\hline $\begin{array}{l}\text { Professional \& Business } \\
\text { Services }\end{array}$ & 0.809 & 12.6 & 8.9 & 5.0 & 14.2 & 44.2 \\
\hline Health and Education & 0.875 & 14.6 & 4.6 & 3.6 & 7.2 & -0.6 \\
\hline Leisure \& Hospitality & 0.742 & 10.1 & 9.4 & 4.6 & 24.1 & 8.9 \\
\hline Other Services & 0.865 & 4.1 & 2.9 & 1.2 & 1.9 & -5.6 \\
\hline Government & 0.887 & 17.4 & 1.6 & 4.3 & 6.2 & -15.6 \\
\hline Region & & & \multicolumn{4}{|c|}{ Contributions to National Changes } \\
\hline Northeast & 0.845 & 19.6 & 13.8 & 9.1 & 8.5 & 5.2 \\
\hline Midwest & 0.806 & 22.8 & 20.7 & 34.9 & 25.7 & 44.2 \\
\hline South & 0.823 & 35.8 & 40.6 & 25.4 & 43.6 & 40.3 \\
\hline West & 0.783 & 21.7 & 24.9 & 30.6 & 22.2 & 10.2 \\
\hline
\end{tabular}

Source: Authors' calculations using JOLTS micro data and published statistics. See text and DFH for descriptions of how we calculate the job-filling rate and recruiting intensity per vacancy. The industry and regional contributions are for the national changes constructed by aggregating the industry or regional changes, respectively. 
Figure A.1 Job-Filling Rates and Recruiting Intensity by Industry, January 2001 - September 2011

Goods-Producing and Nonprofessional Services Job-Filling Rate

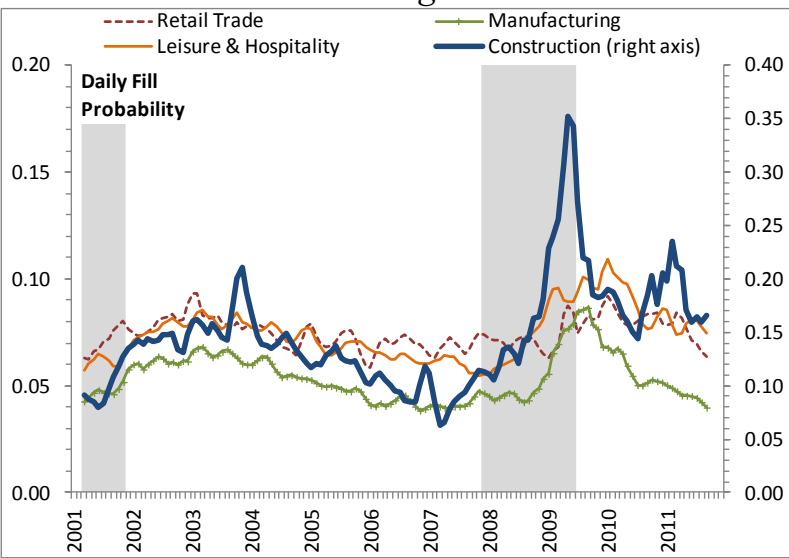

\section{Recruiting Intensity}

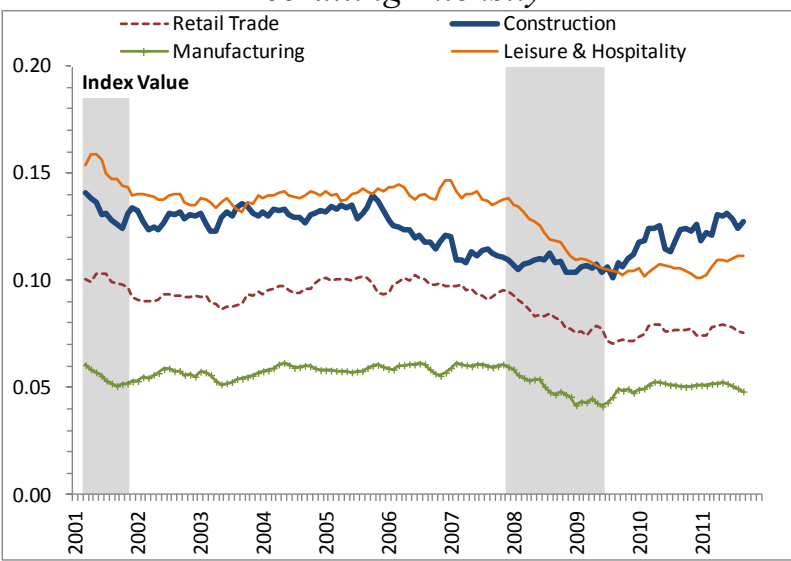

Professional Service Industries Job-Filling Rate

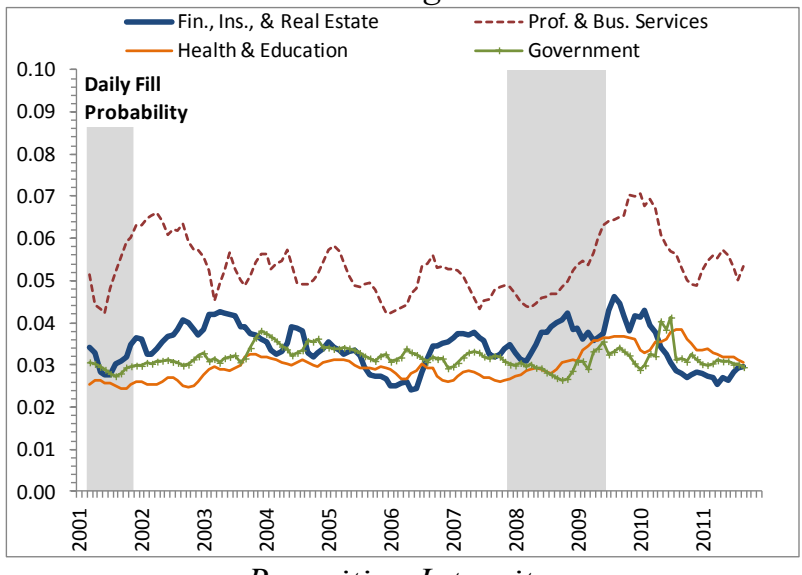
Recruiting Intensity

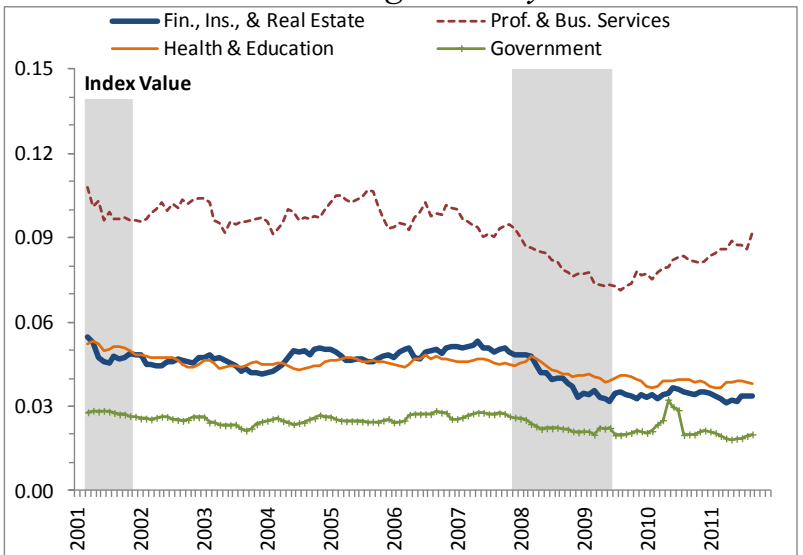

Source: Authors' calculations using JOLTS data. See text for descriptions of how we calculate the jobfilling rate and recruiting intensity. 
Figure A.2 Job-Filling Rates and Recruiting Intensity by Region, January 2001 - September 2011

(a) Job-Filling Rate

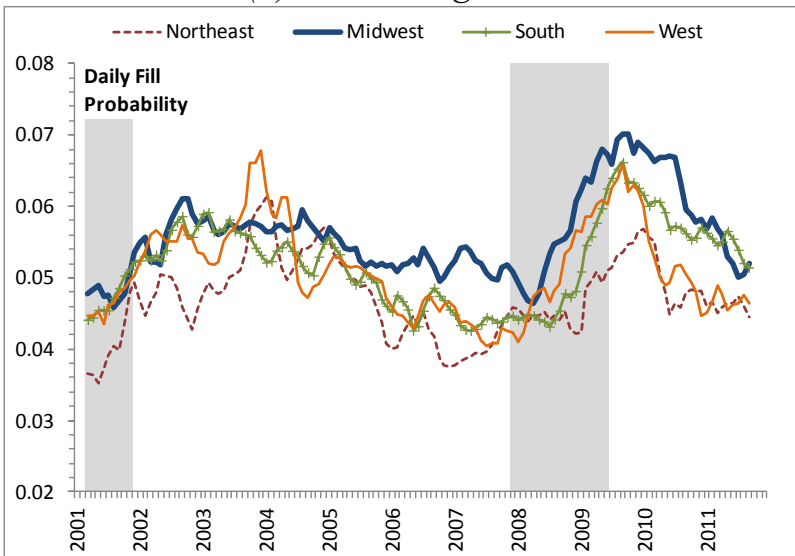

(b) Recruiting Intensity

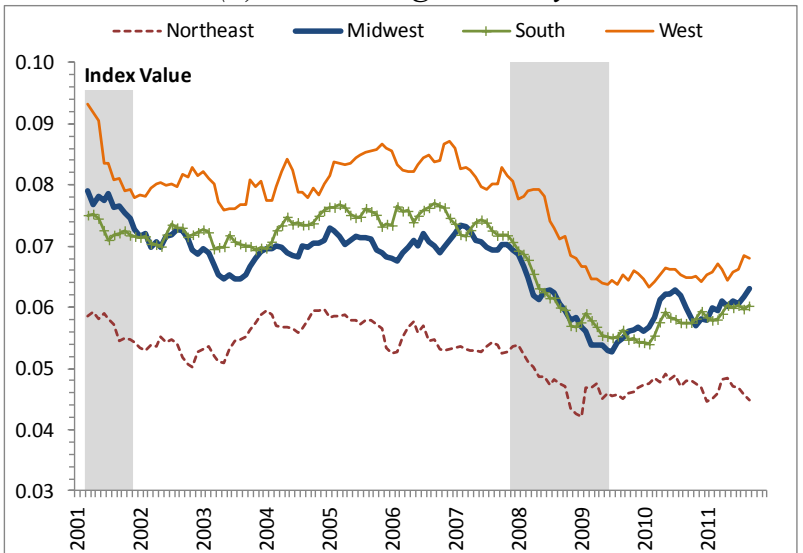

Source: Authors' calculations using JOLTS data. See text and DFH for descriptions of how calculate the job-filling rate and recruiting intensity per vacancy. 